\section{NOTES ON BREEDING OF THE HIMALAYAN BLACK BEAR (SELENARCTOS THIBETANUS) AT NANDANKANAN ZOOLOGICAL PARK, BHUBANESWAR}

\author{
L.N. Acharyo ${ }^{1}$ and Vinod Kumar ${ }^{2}$ \\ ${ }^{1}$ M-71, Housing Board Colony, Baramunda, Bhubaneswar, Orissa \\ 751003, India. \\ ${ }^{2}$ Former Director, Nandankanan Zoological Park, Bhubaneswar, \\ Orissa, India.
}

A pair of Himalayan Black Bears (Selenarctos thibetanus) were received at the Nandankanan Zoological Park, Bhubaneswar in July 1978 at an estimated age of about 18 months through an animal dealer. They were housed in a spacious arch-shaped open air enclosure with a water moat on the viewers' side and a $5 \mathrm{~m}$ vertical high wall made of stone masonary on the remaining portions of the enclosure. Each adult bear was fed with bread $(700 \mathrm{~g})$, cooked rice $(700 \mathrm{~g})$, cooked black gram $(100 \mathrm{~g})$, sweet potato $(250 \mathrm{~g})$, pumpkin $(250 \mathrm{~g})$, carrot $(250 \mathrm{~g})$, banana $(250 \mathrm{~g})$, milk $(500 \mathrm{ml})$, and honey $(25 \mathrm{ml})$ per day.

Matings were observed from March to May. The female gave birth to her first litter on 3 January 1982. So far, 15 cubs have been born in ten litters to the female of the pair and one of their female offsprings. The mean litter size was 1.5 cubs per litter. There were seven males, three females and sexes of the remaining five could not be recorded. Seven births were recorded during December and three births during January. The gestation period calculated from the last day of mating to birth observed twice during 1981 and 1985 were 248 and 252 days, respectively.

The eyes of the new born cubs were closed at birth and of the two cubs under observation one opened its eyes on the $33^{\text {rd }}$ day and the other on the $37^{\text {th }}$ day. A female bear born in the Park on 24 December 1988 gave birth to her first litter of two cubs on 28 December 1992 at the age of four years and five days. The inter-parturition interval observed among the two females in eight cases varied from 11 months and 23 days to three years and 14 days. It mostly depended on the period of survival of the new born cubs or period of separation of the female bear from its male partner. Out of 15 zoo-born cubs, two were still-born, four were cannibalised and three died from various causes within four months of age.

According to Prater (1998), the mating season is late autumn and cubs, usually two or more are produced late in winter and early in spring. Mating was observed in the month of May and two litters of one and two cubs respectively were born during the third week of January 1976 and January 1997 at Jawaharlal Nehru Biological Park, Bokaro Steel City (Chakraborty et al., 1998). They have also given the gestation period on two observation as 243 and 245 days. The birth of a litter of two cubs with their eyes closed was recorded in January 1990 at Kamala Nehru Zoo, Indore (Mahodaya, 1991). The litter size of nine births at National Zoological Park, New Delhi during 1961 to 1969 was one or two with a mean of 1.6 cubs per litter and all the births were recorded during January-March (Sankhla \& Desai, 1969). According to Asdell (1964), this species probably mates in autumn and the young, usually two, are born in spring. In India, the usual litter size of this bear is two and they are born with their eyes closed (Walker et al., 1964).

\section{References}

Asdell, S.A. (1964). Patterns of Mammalian Reproduction. Second Edition. Cornell University Press. Ithaca, New York, 443pp.

Chakraborty, G., N.A. Saifi and M.A. Salam (1998). Captive Breeding and Management of Himalayan Black Bear (Selenarctos thibetanus) at Jawaharlal Nehru Biological Park. Zoos' Print 13(3): 20.

Mahodaya,A.K. (1991). Breeding the Himalayan Black Bear at Kamala Nehru Zoo, Indore. Zoos' Print 6(3): 6.

Prater, S.H. (1998). The Book of Indian Animals, pp.141-142. Bombay Natural History Society, Mumbai.

Sankhla, K.S. and J.H. Desai (1960). Reproductive pattern of some Indian Mammals. Cheetal 12(1): 114-129.

Walker, E.P. (1964). Mammals of the World. Volume II. The Johns Hopkins Press, Baltimore, 1172pp.
${ }^{2}$ Present Address: Director (Operation), Orissa Forest Development Corporation Ltd, Kahrvela Nagar, Bhubaneswar, Orissa, 751001, India

Received 11 October 2002

Finally accepted 20 June 2003 